\title{
PERANCANGAN TAS SEKOLAH BERBASIS MODEL ERGONOMIC - ANTHROPOMETRY GUNA PENGEMBANGAN SENTRA INDUSTRI TAS DI KABUPATEN GRESIK
}

\author{
Deny Andesta \\ Program Studi Teknik Industri \\ Universitas Muhammadiyah Gresik \\ Email : deny.andesta@gmail.com
}

\begin{abstract}
ABSTRAK
Calah satu sentra indusri kecil menengah yang potensial di Kabupaten Gresik adalah industri kerajinan tas. Tas $\checkmark$ sekolah produksi sentra industri kecil menengah tersebut memiliki banyak kelemahan. Berdasarkan evaluasi analisa anthropometri, dan biomechanical dengan software ergo-mannequin serta analisa subjektifitas pada tas sekolah yang dipergunakan oleh siswa-siswi sekolah selama ini tidak ergonomis. Terdapat beberapa perubahan dan tambahan yang sebaiknya dilakukan pada tas ransel yang diproduksi oleh industri kecil menengah agar menjadi ergonomis seperti perancangan ulang tinggi tas menjadi $45 \mathrm{~cm}$, lebarnya $33 \mathrm{~cm}$, tebal tas : $16 \mathrm{~cm}$, dengan genggaman tangan : $9.2 \mathrm{~cm}$, handel $=10.8 \times 4.7 \mathrm{~cm}$ dan penambahan penyangga yang juga berfungsi sebagai pengalir udara (airflow) pada punggung.
\end{abstract}

Kata kunci : Anthropometri, Ergonomis, Biomechanical

\section{PENDAHULUAN}

\section{Latar Belakang}

Pemerintah Indonesia mencanangkan 2009 sebagai tahun industri kreatif dengan fokus pengembangan 14 sub sektor industri, diantaranya sub sektor kerajinan, desain, riset serta pengembangan sebagai upaya mengatasi dampak krisis ekonomi global yang terjadi tahun ini. Di Indonesia terdapat 50 juta industri, 49 juta atau 99 persen merupakan usaha kecil menengah (BPS, 2007). Salah satu sentra indusri kecil menengah potensial di Kabupaten Gresik adalah industri kerajinan tas yang merupakan usaha UKM dengan pertumbuhan positif (BPS 2008). UKM tersebut memproduksi berbagai macam produk tas, diantaranya tas sekolah, tas kerja, dompet dan lainlain. Dari berbagai macam produk yang dihasilkan disentra industri tersebut, produk tas sekolah yang paling diminati konsumen.

Penelitian yang dilakukan oleh Mahbubah (2004) dapat disimpulkan bahwa selama ini tas sekolah produksi sentra industri kecil menengah tersebut memiliki banyak kelemahan terutama dari segi desain produk. Dan ini berdasarkan keluhankeluhan konsumen siswa-siswi sekolah yaitu tas sekolah mudah sobek, kurang nyaman dipakai, model monoton, warnanya cepat pudar, serta menimbulkan nyeri pada bahu yang disebabkan tidak ergonomis.

Hal tersebut merupakan permasalahan serius dan perlu dicari solusi agar sentra industri kecil di Kabupaten Gresik mampu menciptakan produk tas sekolah yang berkualitas dengan mengakomodasi keinginan-keinginan konsumen sesuai dengan prinsip-prinsip ergonomi agar mampu meningkatkan daya saing serta meningkatkan area pemasaran dan mampu bertahan ditengan persaingan usaha yang semakin kompetitif.

Selama ini perhatian pemerintah dalam memajukan sentra industri kecil menengah tersebut kurang komprehensif serta melakukan usaha pembinaan yang hanya berfokus pada pemberian modal. Berdasarkan penelitan awal dapat 
diketahui bahwa modal bukan merupakan faktor kendala utama yang menjadi penyebab penurunan omset pada sentra industri kecil. Keterbatasan teknologi merupakan hambatan terbesar dalam pengembangan usaha.

Penelitan mengenai ergonomic anthropometry serta pemanfaatan software ergo mannequin untuk diaplikasikan pada usaha kecil menengah di Indonesia masih sangat jarang.

\section{Tujuan Penelitian}

Penelitian ini memiliki tujuan sebagai berikut :

1. Melakukan analisa ketidaklayakan tas sekolah serta mengidentifikasi dampak ketidak layakan terhadap tumbuh kembang siswa sekolah.

2. Mengidentifikasi keinginan atau kebutuhan konsumen dalam perancangan tas sekolah yang ergonomis.

3. Merancang dan membuat prototype tas sekolah yang ergonomis berbasis perangkat lunak ergomannequin, guna meningkatkat kualitas dan daya saing produk.

\section{Manfaat Penelitian}

Manfaat yang diperoleh dari penelitian ini adalah :

1. Bagi konsumen yaitu siswa-siswi usia sekolah bisa menggunakan tas sekolah yang nyaman dipakai, praktis atau simpel, harga terjangkau, kualitasnya baik dengan model menarik dan ergonomis sehingga mampu meminimalisir terhambatnya tumbuh kembang siswa sekolah akibat tas yang kurang ergonomis.

2. Bagi produsen pengrajin tas sekolah, mampu mengembangkan usahanya untuk memenuhi keinginan konsumen dalam merancang tas sekolah yang ENASE (efektif, nyaman, aman, sehat, efisien) serta memproduksi tas sekolah yang ergonomis yang mampu meningkatkan nilai jual dan daya saing dipasaran.

3. Bagi pengambil kebijakan, produk penelitian ini diharapkan mampu mengembangkan potensi daerah yang belum dimanfaatkan secara optimal dalam perencanaan dan pengembangan usaha kecil menengah dan dijadikan format baku dalam mengembangkan usaha kecil menengah.

4. Bagi peneliti diharapkan dapat menggunakan hasil penelitian ini dan mengembangkan modelmodel penelitian ergonomis dimasa yang akan datang.

\section{TINJAUAN PUSTAKA}

\section{Ergonomi}

Ergonomi berasal dari bahasa yunani yaitu "ergo" yang berarti kerja dan "Nomos" yang berarti hukum, aturan, prinsip atau kaidah. Dengan demikian ergonomi adalah suatu cabang ilmu yang sistematis untuk memanfaatkan informasi mengenai sifat, kemampuan dan keterbatasan manusia untuk merancang suatu sistem itu dengan baik, yaitu mencapai tujuan yang diinginkan melalui pekerjaan itu dengan efektif, efisien, aman dan nyaman.

Fokus dari ergonomi adalah manusia dan interaksinya dengan produk, peralatan, fasilitas, prosedur serta lingkungan yang digunakan dalam bekerja dan hidup seharihari. Perhatian utama dari ergonomi adalah pada manusia dan bagaimana rancangan suatu produk atau barang mempengaruhi manusia yang menggunakannya. Ergonomi yang juga disebut dengan "human factor" berusaha mencari perubahan terhadap produk atau barang yang digunakan manusia agar dapat meningkatkan kemampuan sekaligus mengatasi keterbatasan-keterbatasan manusia.

Pendekatan yang ada dalam disiplin ergonomi adalah penerapan secara sistematis dari informasi yang relavan tentang kemampuan, keterbatasan, karakteristik dan perilaku manusia dalam perancangan, fasilitas dan lingkungan kerja yang dipakai.

Sedangkan menurut Sritomo Wignjosoebroto (1995, hal 57) pokok-pokok kesimpulan mengenai disiplin ergonomi, yaitu sebagai berikut :

- Fokus perhatian ergonomi berkaitan dengan aspek manusia di dalam perancangan "Manmade Objects", fasilitas dan lingkungan kerja.

- Tujuan utama dari ergonomi : 
1. Memperbaikiperformance sepertimenambah kecepatan kerja, akurasi, keselamatan kerja dan mengurangi kesalahan

2. Mengurangi waktu pelatihan biaya

3. Memperbaiki pendayagunaan SDM melalui pengurangan tingkat ketrampilan yang diperlukan

4. Meminimalkan kerusakan peralatan yang disebabkan oleh human error

5. Memperbaiki kanyamanan manusia dalam bekerja.

Dengan memperhatikan hal-hal tersebut maka penelitian tentang ergonomi akan memerlukan dukungan berbagai disiplin keilmuan seperti psikologi, anthropologi, faal atau anatomi dan tekhnologi (engineering).

Sedangkan indicator diperlukannya ergonomi dalam sistem industri dapat disebutkan sebagai berikut :

a. Pekerja sering membuat kesalahan dalam pekerjaannya

b. Sering terjadi kecelakaan dalam melaksanakan pekerjaannya

c. Pekerja cepat mengalami kelelahan

d. Personal dan fatigue allowance terlalu tinggi

e. Banyak permintaan untuk pindah ke pekerjaan lain

f. Kualitas produk rendah.

\section{Kelelahan}

Secara garis besar dapat dikatakan bahwa kelelahan merupakan keadaan suatu individu, dimana terjadi penurunan kekuatan dan kontraksi otot serta perlambatan gerakan aktivitas yang sedang dilakukanya. Hal ini dapat ditimbulkan oleh dua hal, yaitu akibat fisik (fosiologis atau kimia) dan akibat kelelahan mental (psikologis).

Kelelahan fisiologis adalah kelelahan yang timbul karena adanya perubahan fisiologis dalam tubuh manusia. Pada saat terjadi kegiatan, terjadi proses kimia dalam otot, antara lain penyediaan energi yang diperlukan. Pada saat relaksasi, cadangan tenaga akan dibentuk kembali. Jika konsumsi energi melampaui kemampuan 116 pembentukan pembentukan kembali energi, akan menurunkan efesiensi kerja dan hal inilah yang menimbulkan adanya kelelahan.

Pada kalelahan fisiologis sebenarnya merupakan kelelahan yang semu karena hal ini timbul dari perasaan yang ada dalam pikiran seseorang, seperti bosan, keadaan yang monoton, lingkungan yang tidak cocok, tanggung jawab, kekhawatiran serta konflik. Pikiran semacam inilah yang kemudian disadari serta dianggap sebagai kelelahan otot.

\section{Anthropometri}

Istilah Anthropometri berasal dari kata "anthro" yang berarti manusia dan "metri" yang berarti ukuran. Secara definitive anthropometri dapat dinyatakan sebagai suatu studi yang berkaitan dengan pengukuran dimensi tubuh manusia. Anthropometri secara luas akan digunakan sebagai bahan pertimbangan-pertimbangan ergonomis dalam proses perancangan (design) produk maupun sistem kerja yang akan memerlukan interaksi manusia (Wignjosoebroto, 1995). Data anthropometri yang berhasil diperoleh akan diaplikasikan secara luas dalam hal:

a. Perancangan areal kerja (work station, interior mobil, dan lain-lain)

b. Perancangan peralatan kerja seperti mesin, equipment, perkakas (tools) dan sebagainya

c. Perancangan produk-produk konsumtif (pakaian, meja / kursi, komputer, dan lainlain)

d. Perancangan lingkungan kerja fisik

Dengan demikian dapat disimpulkan bahwa data anthropometri akan menentukan bentuk, ukuran dan dimensi yang tepat yang berkaitan dengan produk yang dirancang dan manusia yang akan menggunakan produk tersebut. Dalam kaitan ini produk harus mampu mengakomodasikan dimensi tubuh manusia dari populasi terbesar yang akan menggunakan produk hasil rancangan tersebut, sekurang-kurangnya $90 \%-95 \%$ dari populasi yang menjadi target dalam pemakaian suatu produk. Rancangan produk yang dapat diatur secara fleksibel jelas memberikan kemungkinan lebih besar bahwa produk tersebut akan mampu dioperasikan oleh setiap orang meskipun ukuran tubuh mereka berbeda-beda. Kemampuan 
menyesuaikan (adjustability) suatu produk merupakan suatu persyaratan yang sangat penting dalam proses perancangan terutama untuk produkproduk yang berorientasi ekspor.

\section{Penerapan Data Anthropometri dalam Perancangan}

Data anthropometri yang menyajikan data ukuran dari berbagai macam anggota tubuh manusia dalam persentil tertentu akan sangat besar manfaatnya pada saat suatu produk nantinya bisa sesuai dengan ukuran tubuh manusia yang akan mengoperasikannya, maka prinsipprinsip apa yang harus diambil di dalam aplikasi data anthropometri tersebut harus ditetapkan terlebih dahulu seperti diuraikan berikut ini:

a. Prinsip perancangan produk bagi individu dengan ukuran yang ekstrim disini rancangan produk dibuat agar bisa memenuhi 2 sasaran produk, yaitu:

1) Bisa sesuai untuk ukuran tubuh manusia yang mengikuti klasifikasi ekstrim dalam arti terlalu besar atau kecil bila dibandingkan dengan rata-ratanya.

2) Tetap bisa digunakan untuk memenuhi ukuran tubuh yang lain (mayoritas dari populasi yang ada)

Agar bisa memenuhi sasaran pokok tersebut maka ukuran yang diaplikasikan ditetapkan dengan cara:

1) Untuk dimensi minimal yang harus ditetapkan dari suatu rancangan produk umumnya didasarkan pada nilai persentil yang terbesar seperti 90-th, 95th, atau 99-th persentil. Contoh konkrit pada kasus ini bisa dilihat misalnya pada penetapan ukuran minimal dari lebar dan tinggi pintu darurat, kursi, dan lain-lain.

2) Untuk dimensi maksimal yang harus ditetapkan diambil berdasarkan nilai persentil yang paling rendah (1-th, 5-th, 10-th persentil) dari distribusi data anthropometri yang ada. Hal ini diterapkan sebagai contoh dalam penetapan jarak jangkauan dari suatu mekanisme kontrol yang haru dioperasikan oleh seorang pekerja. Secara umum aplikasi data anthropometri untuk perancangan produk ataupun fasilitas kerja akan menetapkan nilai 5-th persentil untuk dimensi maksimal dan 95-th persentil untuk dimensi minimalnya.

b. Prinsip perancangan produk yang bisa dioperasikan di antara rentang ukuran tertentu. Disini rancangan bisa diubahubah ukurannya sehingga cukup fleksibel dioperasikan oleh setiap orang yang memiliki berbagai macam ukuran tubuh. Contoh yang paling umum dijumpai adalah perancangan kursi mobil yang dalam hal ini letaknya bisa digeser maju / mundur dan sudut sandarannya pun bisa diubah-ubah sesuai dengan yang diinginkan. Dalam kaitannya untuk mendapatkan rancangan yang fleksibel semacam ini, data anthropometri yang umum diaplikasikan adalah dalam rentang nilai 5-th persentil sampai dengan 95-th persentil.

c. Prinsip perancangan produk dengan ukuran rata-rata. Dalam hal ini rancangan produk didasarkan terhadap rata-rata ukuran manusia. Problem pokok yang dihadapi dalam hal ini justru sedikit sekali mereka yang berada dalam ukuran rata-rata. Di sini produk dirancang dan dibuat untuk mereka yang berukuran sekitar rata-rata, sedangkan bagi mereka yang memiliki ukuran ekstrim akan dibuatkan rancangan tersendiri.

Berkaitan dengan aplikasi data anthropometri yang diperlukan dalam proses perancangan produk, maka ada beberapa saran / rekomendasi yang bisa diberikan sesuai dengan langkah-langkah sebagai berikut:

1) Pertama kali harus ditetapkan anggota tubuh yang nantinya akan difungsikan untuk mengoperasikan rancangan tersebut.

2) Tentukan dimensi tubuh yang penting dalam proses perancangan tersebut, dan juga perlu diperhatikan apakah perlu menggunakan data structure body dimension atau functional body dimension. 
3) Tentukan populasi terbesar yang harus diantisipasi, direkomendasikan dan menjadi target utama pemakai rancangan tersebut. Hal ini lazim dikenal sebagai "market segmentation", seperti mainan anak-anak, peralatan rumah tangga untuk wanita dan lain-lain.

4) Tetapkan prinsip ukuran yang harus diikuti, sebagai contoh apakah ukuran rancangan tersebut untuk orang yang mempunyai ukuran ekstrim, rentang ukuran yang fleksibel atau ukuran rata-rata.

5) Pilih persentase populasi yang harus diikuti yaitu 90-th, 95-th, 99-th, atau nilai persentil yang lain yang dikehendaki.
6) Untuk setiap dimensi tubuh yang telah diidentifikasikan, selanjutnya pilih nilai ukuran dari tabel data anthropometri yang sesuai. Aplikasikan data tersebut dan tambahkan faktor kelonggaran (allowance) bila diperlukan seperti halnya tambahan ukuran oleh akibat tebalnya pakaian yang harus dikenakan oleh operator, pemakaian sarung tangan dan lain-lain.

Selanjutnya untuk memperjelas mengenai data anthropometri untuk bisa diaplikasikan dalam berbagai rancangan produk ataupun fasilitas kerja, yaitu dapat dilihat pada gambar di bawah ini (Wignjosoebroto, 1995):

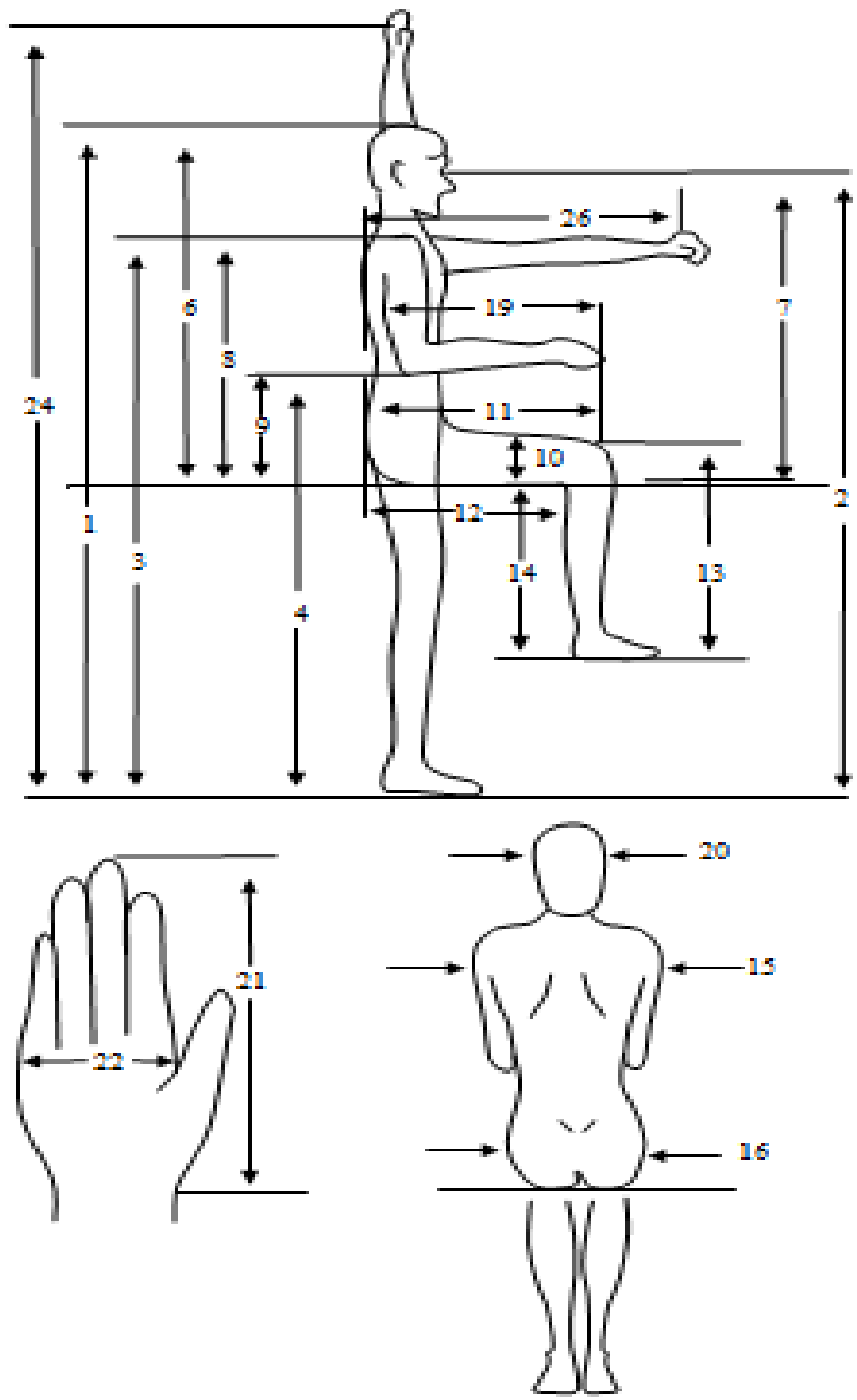

Gambar 1. Data anthropometri yang diperlukan untuk perancangan produk Keterangan: 
1 = Dimensi tinggi tubuh dalam posisi tegak (dari lantai sampai dengan ujung kepala)

2 = Tinggi mata dalam posisi berdiri tegak

3 = Tinggi bahu dalam posisi berdiri tegak

4 = Tinggi siku dalam posisi berdiri tegak (siku tegak lurus)

5 = Tinggi kepalan tangan yang terjulur lepas dalam posisi berdiri tegak (dalam gambar tidak ditunjukkan)

6 = Tinggi tubuh dalam posisi duduk (diukur dari alas tempat duduk / pantat sampai dengan kepala)

7 = Tinggi mata dalam posisi duduk

8 = Tinggi bahu dalam posisi duduk

9 = Tinggi siku dalam posisi duduk (siku tegak lurus)

$10=$ Tebal atau lebar paha

$11=$ Panjang paha diukur dari pantat sampai dengan ujung lutut

$12=$ Panjang paha yang diukur dari pantat sampai dengan bagian belakang dari lutut / betis

13 = Tinggi lutut yang bisa diukur baik dalam posisi berdiri ataupun duduk

$14=$ Tinggi tubuh dalam posisi duduk yang diukur dari lantai sampai dengan paha

$15=$ Lebar dari bahu (bisa diukur dalam posisi berdiri ataupun duduk)

$16=$ Lebar pinggul / pantat

$17=$ Lebar dari dada dalam keadaan membusung (tidak tampak ditunjukkan dalam gambar)

$18=$ Lebar perut

19 = Panjang siku yang diukur dari siku sampai dengan ujung jari-jari dalam posisi siku tegak lurus.

$20=$ Lebar kepala

21 = Panjang tangan diukur dari pergelangan sampai dengan ujung jari

$22=$ Lebar telapak tangan

$23=$ Lebar tangan dalam posisi tangan terbentang lebar-lebar kesamping kiri kanan (tidak ditunjukkan dalam gambar)

$24=$ Tinggi jangkauan tangan dalam posisi berdiri tegak, diukur dari lantai sampai dengan telapak tangan yang terjangkau lurus ke atas (vertikal)

$25=$ Tinggi jangkauan tangan dalam posisi duduk tegak diukur seperti halnya no. 24 tetapi dalam posisi duduk (tidak ditunjukkan dalam gambar)

$26=$ Jarak jangkauan tangan yang terjulur ke depan diukur dari bahu sampai ujung jari tangan

Data anthropometri dibuat sesuai dengan ukuran tubuh laki-laki dan perempuan, harga ratarata $(X)$, standart deviasi $\left(\sigma_{x}\right)$, secara persentil tertentu (5-th, 95-th, dan sebagainya).

\section{Biomekanika}

Dasar-dasar Biometika

Dalam gerakan pada sistem kerangka otot, otot bereaksi terhadap tulang untuk mengendalikan gerak rotasi di sekitar sambungan tulang beberapa sistem pengungkit menjelaskan hal tersebut. Dalam sistem ini bertindak sebagai sistem mekanis yang berfungsi untuk suplai energi kinetic dan gerakan angular (Eko Nurmianto, 1996 ; hal 33-42).

a. Sistem Pengungkit I

Contoh Sistem Pengungkit I :

- Otot triceps menarik ulang untuk menggerakkan siku

- Otot Quadriceps menarik tibia melalui patella untuk menggerakkan lutut

b. Sistem Pengungkit II

Contoh Sistem Pengungkit II

- Otot Biceps menarik radius untuk mengangkat siku

- Otot Bracialis menarik ulna untuk mengangkat siku

- Otot Deltoid menarik humerus untuk mengangkat bahu

Perbedaan Antara Gaya Statis dan Gaya Dinamis

Gaya otot dikeluarkan tanpa menghasilkan suatu 
kerja, hal ini terjadi arena gerakan otot tersebut terhambat dalam suatu sistem kerja. Misalnya mengangkat badan yang terlalu berat.

Memanjang atau mendekatnya otot menghasilkan suatu kerja atau dengan kata lain, gaya otot dikeluarkan dan menghasilkan suatu kerja. Hal ini dikategorikan menjadi dua bagian, yaitu :

a. Konsentris : memendeknya otot sambil tetap menahan sesuatu tegangan

Misalnya : mengangkat beban (kerja positif)

b. Eksentris : memanjangnya otot sambil tetap menahan suatu tegangan dan gerakannya berlawanan dengan tegangannya.

Misalnya : meletakkan kembali setelah mengangkat (kerja negatif)

Otot dapat mengeluarkan gaya berlebihan pada gerakan eksentris sedangkan untuk beban yang sama otot akan lebih aktif pada gerakan konsentris yang mana jauh lebih besar konsumsi gaya yang dikeluarkan.

Untuk dasar dari analisa biomekanik untuk hukum Newton. Hal tersebut sebagai dasar permodelan biomekanik, ketiga teori tersebut untuk :

1. Suatu massa akan tetap dalam keadaan diam atau bergerak kecuali bila ada gaya luar yang bekerja padanya

2. Gaya sebanding dengan percepatan

3. Setiap gaya aksi akan menghasilkan reaksi yang sama besar tetapi arahnya berlawanan.

Hukum tersebut digunakan secara luas dalam biomekanik untuk menggambarkan keadaan tubuh atau segmen.

Model Statis Satu Segmen (Single Segment Model Static)

Untuk menjelaskan model ini di berikan contoh seorang operator yang memegang massa $20 \mathrm{~kg}$ dengan menggunakan presentase 150,12 2 $\mathrm{km}$ di tentukan besar dan arah gaya serta momen pentingnya yang dialami persentil $5 \mathrm{~kg}$ karbon

Berat badan dihitung dengan cara sebagai berikut :

$$
\mathrm{W}=\mathrm{m} \cdot \mathrm{g}
$$

Dimana : $\quad \mathrm{W}=$ berat badan (newton)

$$
\begin{aligned}
& \mathrm{M}=\operatorname{massa}(\mathrm{kg}) \\
& \mathrm{g}=\text { gaya gravitasi }\left(9,8 \mathrm{~m} / \mathrm{s}^{2}\right)
\end{aligned}
$$

Sehingga diperoleh :

$$
\mathrm{W}=(20 \mathrm{~kg})\left(9,8 \mathrm{~m} / \mathrm{s}^{2}\right)=196 \mathrm{~N}
$$

Beban setiap tangan dapat dihitung sebagai berikut :

$$
\begin{aligned}
& \sum \mathrm{f}=0 \\
& -196+2 \mathrm{RH}=0 \\
& \mathrm{RH}=98 \mathrm{~N}
\end{aligned}
$$

Untuk 50 persentil pria, memberikan jarak 17,2 $\mathrm{cm}$. (dari siku kepusat gravitasi lengan bawah) dan $35,5 \mathrm{~cm}$ (jarak antara beban pusat gravitasi).

Sedangkan massa lengan bawah adalah $\mathrm{W}_{\mathrm{F}+\mathrm{H}}=$ $15,7 \mathrm{~N}$.

Gaya reaksi dari siku (RE) dapat dihitung sebagai berikut :

$$
\begin{aligned}
& \sum F=0 \\
& -98 N-15,7+R E=0 \\
& R E=113,7 N
\end{aligned}
$$

Sedangkan momen puntar pada siku dapat dihitung sebagai berikut :

$$
\begin{aligned}
& \sum M=0 \\
& (-98 N)(0,355 m)+(-15,7 N)(0.172 \mathrm{~m})+ \\
& M E=0 \\
& M E=37,5 \mathrm{Nm}
\end{aligned}
$$

Perhitungan diatas dibuat dengan menggunakan hukum Newton yang berkaitan dengan gaya reaksi dan momen. Untuk posisi statis jumlah gaya dan momen sama dengan nol sehingga dinamakan kondisi kesetimbangan.

Model Statis Dua Segmen (Two Segmen Static Model)

Model ini berguna untuk menganalisa dua segmen tubuh dalam keadaan statis. Contoh pada gambar Free Body Diagram, dimana diketahui RE $=113,7$ dan $\mathrm{ME}=37,5 \mathrm{Nm}$. Untuk 50 percentil pria diketahui massa lengan atas adalah $20,6 \mathrm{~N}$. 
Jarak siku dengan bahu : 32,9 cm dan jarak pusat gravitasi lengan atas dengan bahu : 13,2 cm.

$$
\begin{aligned}
& \sum \mathrm{F}=0 \\
& \quad-\mathrm{RE}-\mathrm{WuA}+\mathrm{Rs}=0 \\
& -113,7-20,6+\mathrm{Rs}=0 \\
& \mathrm{Rs}=134,3 \mathrm{~N} \\
& \sum \mathrm{M}=0 \\
& \mathrm{MS}=(0,132 \mathrm{~m})(20,6 \mathrm{~N})+(0,329 \mathrm{~m}) \\
& \quad(113,7 \mathrm{~N})+(37,5 \mathrm{Nm}) \\
& \mathrm{MS}=77,6 \mathrm{Nm}
\end{aligned}
$$

Dimana Rs = Gaya yang dialami bahu

Desain Yang Sesuai dengan Kemampuan dan Keterbatasan Manusia

Karena adanya kenyataan bahwa pada saat melakukan kerja fisik seseorang banyak terlibat di dalamnya, maka sebaiknya kita hindari hal seperti beban statis, sikap kerja atau postur yang berlebihan penggunaan tenaga secara berlebihan, konsentrasi beban kerja yang berlebihan, serta konsentrasi beban kerja hanya pada sejumlah bagian otot saja. Begitu juga dengan kerja mental usahakan agar beban mental dapat kita tekan sekecil-kecilnya, bahkan apabila mungkin kita hilangkan.

Sejumlah konsep dasar perancangan kerja yang ergonomi dapat diberikan sebagai berikut :

- Manusia bervariasi

- Manusia semakin berpendidikan

- Manusiamenginginkanuntukmenyampaikan pendapatnya

- Kesehatan dan keamanan adalah penting

- Transportasi dan komunikasi menyebabkan dunia terasa kecil

- Mesin tekhnologi menjadi semakin canggih

- Terdapat perubahan spesialisasi kerja

- Pekerjaan-pekerjaan semakin berhubungan

Bila kita amati butir pertama diatas tentang manusia bervariasi, kelihatan bahwa pada dasarnya suatu desain atau perancangan ditunjukkan pada manusia yang memiliki karakteristik yang berbeda satu sama lain. Sebagai contoh dapat ambil ukuran tubuh manusia, ada umuran yang pendek, ada pula yang tinggi, serta ada orang yang kurus dan ada yang gemuk.

Dalam melakukan desain atau perancangan sistem kerja yang ergonomis, perlu informasi yang lengkap mengenai kemampuan manusia dengan segala keterbatasanya. Salah satu usaha untuk mendapatkan informasi-informasi ini, telah banyak dilakukan menurut empat kelompok besar sebagai berikut : (Iftikar Z. Sutalaksana, 1997 ; hal 64).

a. Penyelidikan tentang display

Yang dimaksud display adalah bagian dari lingkungan yang berkomunikasikan keadaannya pada manusia. Contohnya : kalau kita ingin mengetahui berapa kecepatan motor yang sedang kita kemudikan, maka dengan melihat jarum speedometer kita akan mengetahui keadaan lingkungan dalam hal ini kecepatan motor.

b. Penyelidikan mengenai hasil kerja manusia dan proses pengendaliannya

Dalam hal ini diselidiki tentang aktivitasaktivitas manusia ketika bekerja dan kemudian mempelajari cara mengukur dari setiap aktivitas tersebut, dimana penyelidikan ini banyak berhubungan dengan biomekanik.

c. Penyelidikan mengenai tempat kerja

Agar diperoleh tempat kerja yang baik, dalam arti kata sesuai dengan kemampuan dan keterbatasan manusia, maka ukuranukuran dari tempat kerja tersebut harus sesuai dengan tubuh manusia. Hal-hal yang bersangkutan dengan tubuh manusia ini dipelajari dalam anthropometri.

d. Penyelidikan mengenai lingkungan fisik

Yang dimaksud dengan lingkungan fisik disini meliputi ruangan dan fasilitas yang biasa digunakan oleh manusia, yang keduaduanya banyak mempengaruhi tingkah laku manusia.

\section{METODE}

Pada bagian ini berisi mengenai alur atau kerangka kerja yang terstruktur dan sistematis dalam melakukan penelitian, dimana terdiri dari tahap-tahap yang saling terkait satu sama lainnya. 


\section{Lokasi Penelitian}

Penelitian ini dilakukan di Kabupaten Gresik dengan cara purposive atau dipilih secara sengaja karena karakteristik wilayah yang dipilih sesuai dengan tujuan penelitian. Dalam hal ini dipilih Desa Terate Kecamatan Gresik dengan alasan bahwa daerah tersebut terdapat sentra industri kecil menengah pengrajin tas dan merupakan mayoritas pekerjaan masyarakat setempat. Penelitian ini dilakukan di 3 (tiga) kecamatan yang ada di daerah Gresik, yaitu Kecamatan Manyar, Kecamatan Gresik dan Kecamatan Kebomas. Pemilihan lokasi penelitian ini dikarenakan pada daerahdaerah tersebut banyak terdapat lembaga-lembaga pendidikan formal setingkat pra sekolah, sekolah dasar hingga sekolah menengah.

\section{Langkah-langkah Pemecahan Masalah}

Langkah-langkah pemecahan masalah dapat diuraikan sebagai berikut :

\section{Pengamatan Awal}

Merupakan kegiatan untuk melihat real condition dari produk tas sekolah yang digunakan siswa-siswi sekolah, meliputi pengamatan kepada bentuk desain dan keluhan-keluhan dari siswa.

\section{Perumusan Masalah}

Identifikasi permasalahan ergonomis pada tas yang digunakan siswa-siswi sekolah.

\section{Tinjauan Pustaka}

Melakukan literature review untuk memperoleh landasan teori yang berubungan dengan permasalahan yang diselesaikan

\section{Pengumpulan Data}

Sesuai dengan permasalahan dan tujuan penelitian maka dalam pengumpulan data mengunakan kaidah "snow ball". Sesuai dengan permasalah yang dijelaskan, maka pengumpulan data akan bersifat konteks terfokus, dengan peneliti sebagai utama. Pengumpulan data akan dilaksanaan dengan cara sebagai berikut :

1. Survey, dilakukan pada tempat-tempat penelitian di sentra-sentra industri tas dan beberapa sekolah yang tersebar di tiga kecamatan.

2. Wawancara

Metode pengumpulan data dengan jalan melakukan wawancara langsung pada siswasiswi dan pengrajin tas.

\section{Observasi}

Metode pengumpulan data dengan jalan melakukan pengamatan langsung pada obyek yang akan diteliti. Data anthropometri dan dimensi tas diperoleh dengan mengukur secara langsung.

Data yang diperlukan adalah dimensi tas sekolah yang diproduksi dan dipergunakan siswa-siswi sekolah, dan keluhan-keluhannya. Data anthropometri diperlukan untuk merancang tas sekolah dan mengevaluasi tas produksi ukm.

\section{Pengolahan Data}

Data yang telah didapat, selanjutnya diolah. Data anthropometri dipergunakan sebagai acuan untuk melakukan evaluasi keergonomisan.

\section{Analisa dan Interpretasi}

Menganalisa hasil pengolahan data. Dari hasil pengolahan data didapat ukuran dan dimensi tas yang sesuai dengan anthropometri.

\section{Kesimpulan dan Saran}

Menyimpulkan hasil penelitian dan memberikan rekomendasi desain baru. 


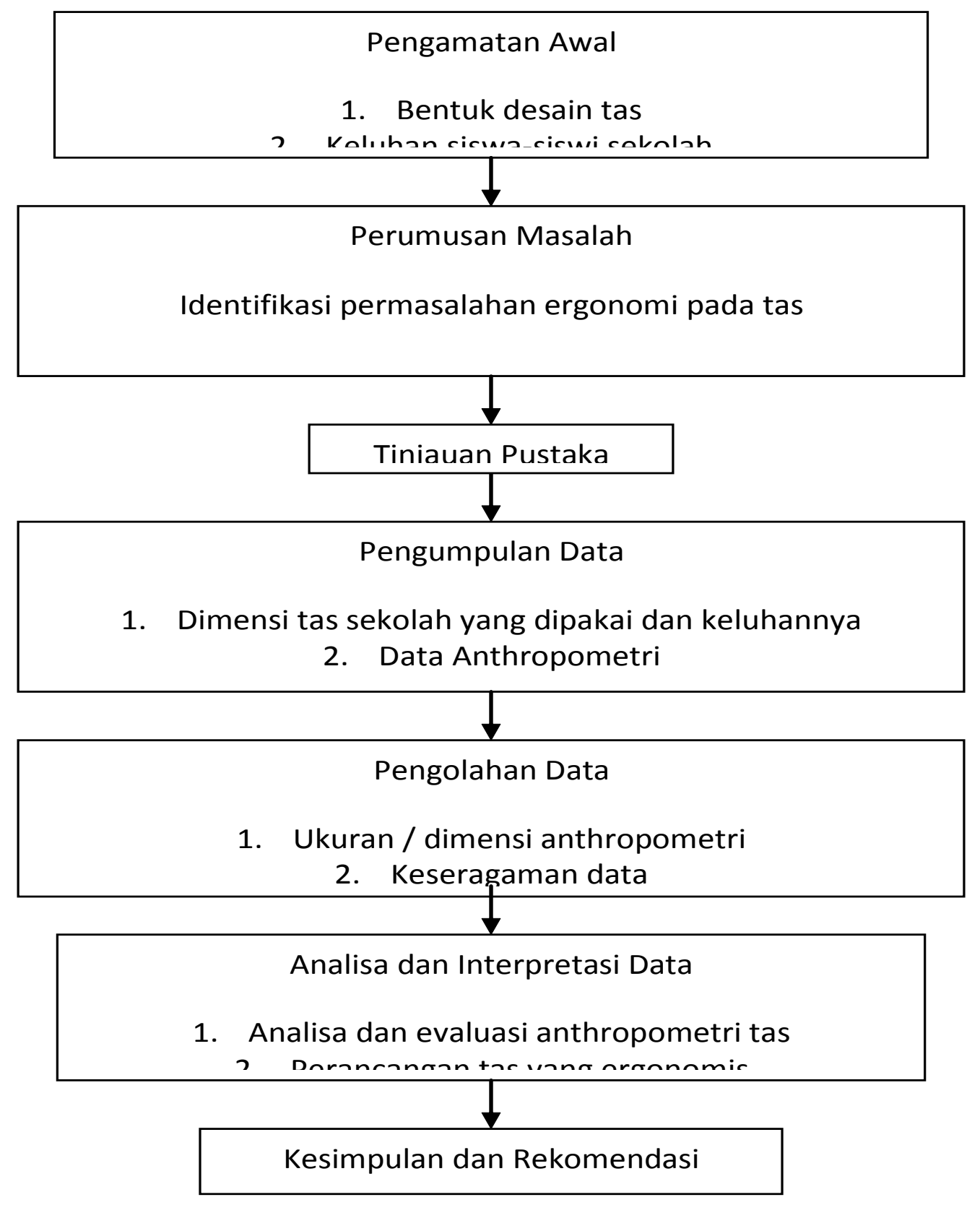

\section{HASIL DAN PEMBAHASAN}

Data Anthropometri Tubuh

Berkaitan dengan perancangan tas sekolah yang ergonomi, maka diperlukan pengamatan dan pengumpulan data-data yang diperlukan. Data anthropometri tubuh ini diperoleh dari pengukuran siswa-siswi sekolah yang terdapat di daerah gresik.

Dimensi tubuh yang diukur dalam penelitian ini merupakan dimensi tubuh yang diperlukan untuk melakukan perancangan ulang ukuran geometri tematika Penelitian

dari tas sekolah. Dimensi tubuh tersebut antara lain :

1. Tinggi bahu dalam posisi duduk (D8)

2. Lebar dari bahu (D15)

3. Lebar pinggul / pantat (D16)

4. Lebar telapak tangan (D22)

\section{Uji Keseragaman Data}

Peta kontrol adalah suatu alat yang tepat guna dalam menguji keseragaman data yang diperoleh 
dari hasil pengamatan. Untuk membuat peta kontrol dihitung rata-rata (mean), batas kontrol atas (BKA), batas kontrol bawah (BKB). Hasil uji keseragaman dapat dilihat pada tabel berikut :

Tabel 1. Hasil Uji Keseragaman Data

\begin{tabular}{|c|c|c|r|r|r|l|}
\hline No. & $\begin{array}{c}\text { Dimensi } \\
\text { Tubuh }\end{array}$ & $\mathrm{N}$ & Rata-rata $(\mathrm{cm})$ & BKA $(\mathrm{cm})$ & BKB $(\mathrm{cm})$ & Keterangan \\
\hline 1. & D8 & 45 & 828.9 & 891.9 & 765.9 & Seragam \\
\hline 2. & D15 & 45 & 387.67 & 414,4 & 360.94 & Seragam \\
\hline 3. & D16 & 45 & 331.9 & 385.5 & 278.3 & Seragam \\
\hline 4. & D22 & 45 & 58.48 & 64.75 & 52.21 & Seragam \\
\hline
\end{tabular}

Pembuatan Tabel Anthropometri

Langkah selanjutnya adalah pembuatan tabel anthropometri yang akan digunakan untuk menganalisa kesesuaian antara geometri tas sekolah dengan dimensi tubuh manusia. Hasil tabel anthropometri dapat dilihat pada tabel berikut.

Tabel 2. Tabel Percentile Anthropometri dimensi tubuh siswa sekolah

\begin{tabular}{|c|r|r|r|r|r|}
\hline Percentiles & $\begin{array}{r}\text { Tinggi Bahu } \\
\text { Duduk }(\mathrm{cm})\end{array}$ & $\begin{array}{c}\text { Lebar } \\
\text { Bahu }(\mathrm{cm})\end{array}$ & $\begin{array}{c}\text { Lebar } \\
\text { Panggul } \\
(\mathrm{cm})\end{array}$ & $\begin{array}{r}\text { Lebar Telapak } \\
\text { Tangan }(\mathrm{cm})\end{array}$ & $\begin{array}{c}\text { Tebal Perut } \\
(\mathrm{cm})\end{array}$ \\
2.5 & 552.3400 & 376.1000 & 305.8430 & 55.3300 & 197.2200 \\
5 & 554.6900 & 376.1300 & 308.8310 & 55.5000 & 198.4100 \\
10 & 561.2000 & 376.5400 & 310.4420 & 55.6000 & 201.2200 \\
50 & 612.4000 & 385.4000 & 335.2800 & 58.6000 & 219.4000 \\
90 & 642.3600 & 401.6400 & 350.2780 & 61.5000 & 241.2800 \\
95 & 647.6800 & 404.3600 & 358.8720 & 61.6700 & 244.8000 \\
97.5 & 648.7350 & 404.6850 & 359.8535 & 61.8700 & 245.3950 \\
\hline
\end{tabular}

Data Ukuran Tas ransel Sebelum Perancangan Ulang

Adapun data ukuran geometris tas sekolah sebelum perancangan ulang sebagai berikut :

1. Tinggi tas ransel

: $50 \mathrm{~cm}$

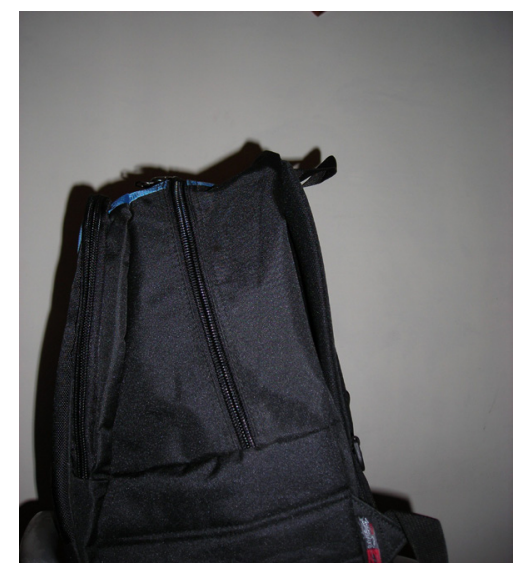

\section{Pendeskripsian Posisi Tubuh}

Pendeskripsian posisi tubuh berguna untuk mengidentifikasi bagian tubuh yang mendapatkan gaya dan momen terbesar akibat posisi tubuh tertentu. Informasi ini berguna sebagai dasar
2. Lebar tas ransel

3. Tebal tas ransel

4. Keliling pegangan tangan

5. Ruang untuk lebar telapak tangan : $20 \mathrm{~cm}$

: $35 \mathrm{~cm}$

$: 14 \mathrm{~cm}$

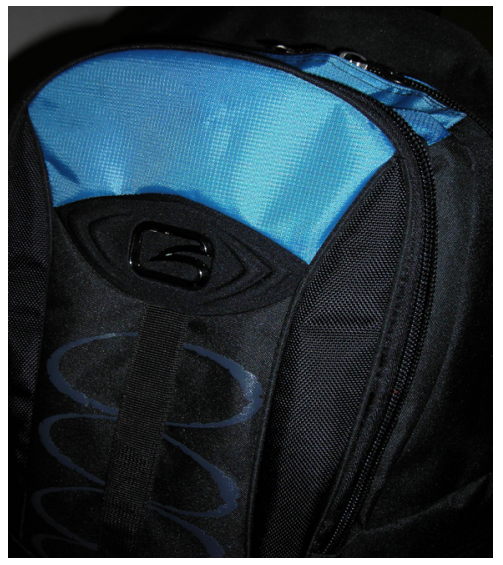

$: 8,5 \mathrm{~cm}$

Gambar 3. Tas yang diproduksi UKM

penentuan posisi tubuh yang perlu diperbaiki dan posisi tubuh yang sebaiknya digunakan saat menggunakan tas ransel sekolah oleh siswa-siswi. Dengan menggunakan software MannequinPro 10.2 maka didapatkan rekapitulasi bagian tubuh yang mendapatkan gaya dan momen yang besar 
akibat posisi tubuh tertentu. Dari perhitungan MannequinPro dapat diketahui bahwa bagian tubuh yang mendapatkan momen terbesar adalah leher, bahu, punggung, paha, lutut dan kepala. Posisi tubuh dengan momen terbesar pada punggung terjadi ketika berjalan.
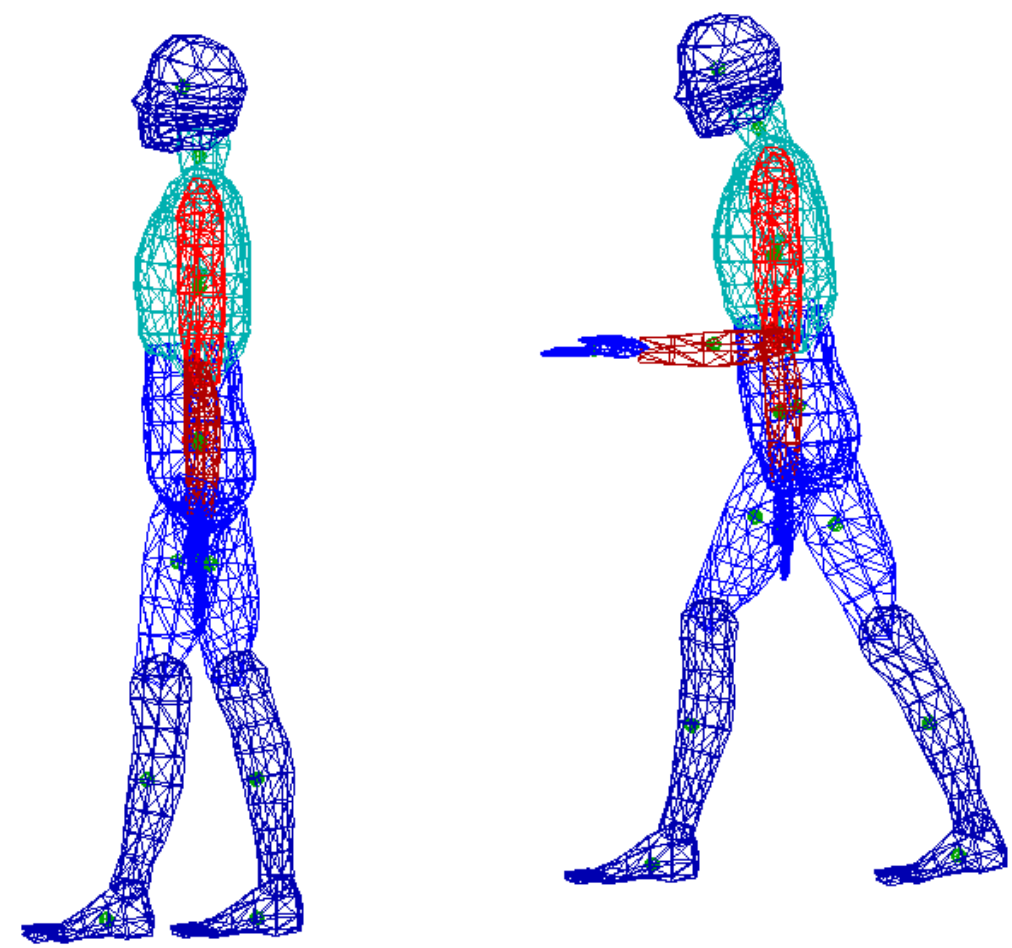

Gambar 4. posisi 1 dan posisi 2 dari biomechanics dari software MannequinPro

Dari analisa momen pada MannequinPro dapat diketahui berbagai akibat dan respon tubuh terutama pungung dan tulang belakang dalam menerima dan mengangkat beban tas ransel, hal ini ditentukan oleh berat beban. Pada posisi 2 dimana punggung dalam posisi terbungkuk dan posisi lengan atas dan bawah yang menekuk akan menimbulkan momen terkecil, dalam hal ini bernilai negatif dari gaya atau beban yang diangkat sehingga saat itu didapat daya angkat terbesar. Secara singkat dapat dikatakan bahwa dengan membungkukkan badan dan menekuk lengan akan memudahkan dalam mengangkat beban tetapi dapat menyebabkan Back Injuries atau rasa sakit pada tulang belakang bila dilakukan secara terus menerus dan dalam jangka waktu yang relatif lama. Punggung dan tulang belakang yang terlalu lama dan menerima beban yang terlalu berat dikhawatirkan akan menimbulkan rasa sakit dan kecelakaan kerja.

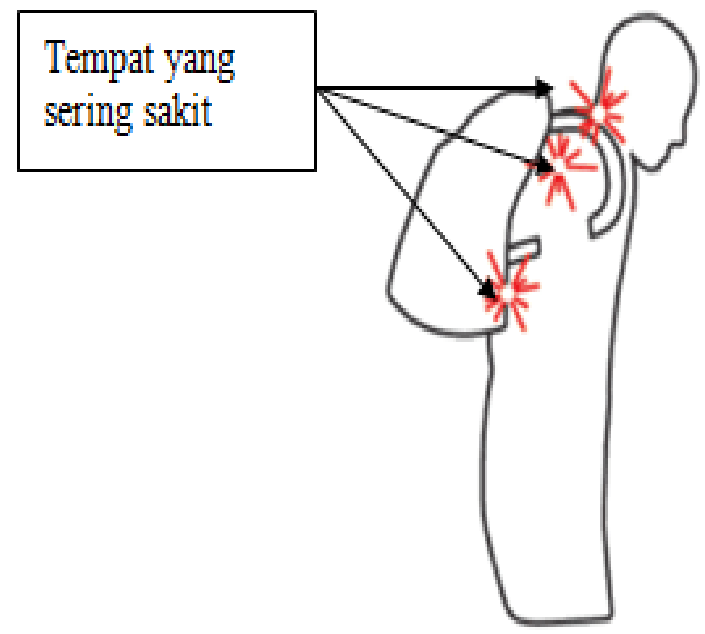

Gambar 5. Area yang sakit pada penggunaan tas ransel 
Tekanan pada punggung, pinggang dan leher dapat dikurangi dengan cara menambahkan penyangga dan ketika punggung menerima tekan dari tas ransel yang cukub berat, akan mengakibatkan tubuh kecenderungan untuk mengimbangi dengan cara membukungkuk badan. Tas ransel akan lebih merapat pada punggung dan hal tersebut akan mengakibatkan tidak adanya aliran udara pada punggung siswa-siswi sekolah. Hal ini akan menambah panas pada punggung pengguna tas ransel. Penambahan penyangga pada punggung, juga mempertimbangkan aliran udara seperti gambar dibawah ini.

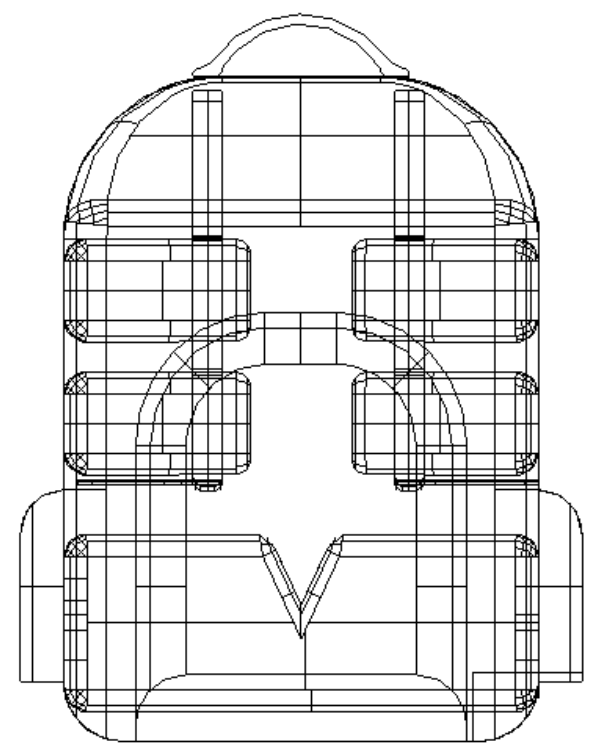

Gambar 6. Penyangga dan airflow pada tas ransel sekolah.

Perancangan Ulang Tas Ransel Sekolah

Penelitian ini dikembangkan berdasarkan penelitian - penelitian pendahuluan serta penelitian sejenis yang dilakukan oleh peneliti lain yang berhubungan dengan faktor ergonomicanthropometry. Penelitian pendahuluan telah dilakukan oleh Mahbubah (2004) dengan melakukan penelitian yang berkaitan dengan keingininan siswa sekolah terhadap tas sekolah, menghasilkan suatu kesimpulan bahwa selama ini tas sekolah produksi sentra industri kecil di Kabupaten Gresik memiliki banyak kelemahan terutama dari segi desain produk berdasarkan data keluhan - keluhan siswa yaitu tas sekolah mudah sobek, kurang nyaman dipakai, model monoton, warnanya cepat pudar, serta menimbulkan nyeri pada bahu.

Perancangan ulang tas sekolah meliputi perancangan ulang ukuran geometris. Perancangan ulang dilakukan dengan mempertimbangkan hasil analisa dari kondisi awal.

\section{a.Perancangan ulang tinggi tas}

- Dimensi tubuh yang di gunakan adalah tinggi bahu duduk (TBD) dan tebal paha (TP)

- Persentil yang di gunakan adalah persentil $2,5=55,2 \mathrm{~cm}$

- Allowance yang di tambahkan adalah tinggi sepatu $=2 \mathrm{~cm}$

- Pertimbangan pemilihan persentil. Ukuran tas tidak boleh lebih tinggi dari tinggi bahu badan. Hal ini di maksudkan agar pengguna yang memiliki ukuran tubuh lebih pendek dapat memakai tas dengan nyaman.

- Jadi ukuran tas rancangan ulang $=55,2-11$ $=45 \mathrm{~cm}$.

b. Perancangan ulang lebar tas

- Dimensi yang di gunakan adalah lebar pinggang ( LP)

- Persentil yang di gunakan adalah persentil $50=33 \mathrm{~cm}$

- Pertimbangan pemilihan persentil. Ukuran tas tidak boleh lebih lebar dari lebar pinggang. 
Hal ini di maksudkan apabila pengguna yang mempunyai lebar pinggang kecil tetap dapat memakai tas dengan nyaman dan apalagi buku yang mereka bawa saat ini sangat besar.

- Jadi lebar tas rangsel adalah $=33 \mathrm{~cm}$

c. Perancangan ulang tebal tas

- Disesuaikan dengan tebal buku yang biasa mereka pakai. Buku yang mereka gunakan saat ini cukup tebal dan juga sering membawa peralatan serta tugas sehingga ukuran tas rangsel adalah $16 \mathrm{~cm}$. Ini juga perlu mempertimbangkan tebal perut.

d. Perancangan ulang genggaman tangan

- Dimensi tubuh yang digunakan adalah panjang telapak tangan (D2), dalam hal ini diambil untuk keliling genggaman tangan.

- Persentil yang digunakan adalah persentil 5 wanita $=8.7 \mathrm{~cm}$.

- Allowance diberikan adalah tebal sarung tangan $=0.5 \mathrm{~cm}$.

- Pertimbangan pemilihan persentil.

- Untuk diameter genggaman tangan diambil keliling genggaman tangan.

e. Perancangan ulang ruang dalam handel

- Dimensi tubuh yang digunakan untuk lebar pegangan tangan adalah lebar telapak tangan dan ruang untuk tinggi pegangan tangan adalah tebal telapak tangan.

- Persentil yang digunakan adalah persentil 97.5 pria, lebar $=10.8 \mathrm{~cm}$ dan tinggi pegangan $=4.7 \mathrm{~cm}$.

\section{KESIMPULAN}

Setelah dilakukan analisa dan interpretasi terhadap hasil pengolahan data, maka langkah terakhir yang dilakukan dalam penelitian ini adalah penarikan kesimpulan

1. Berdasarkan evaluasi analisa anthropometri, serta analisa subjektifitas pada tas sekolah yang dipergunakan oleh siswa-siswi sekolah selama ini tidak ergonomis.

2. Tas sekolah yang diproduksi oleh sentra industri kecil di Kabupaten Gresik memiliki banyak kelemahan terutama dari segi desain produk berdasarkan data keluhan - keluhan siswa yaitu tas sekolah mudah sobek, kurang nyaman dipakai, model monoton, warnanya cepat pudar, serta menimbulkan nyeri pada bahu.

3. Terdapat beberapa perubahan dan tambahan yang sebaiknya dilakukan pada tas ransel yang diproduksi oleh industri kecil menengah agar menjadi lebih ergonomis lagi dalam hal :

a. Perancangan ulang tinggi tas $=45 \mathrm{~cm}$.

b. Perancangan ulang lebar tas $=33 \mathrm{~cm}$.

c. Perancangan ulang tebal tas : $16 \mathrm{~cm}$

d. Perancangan ulang genggaman tangan $=9.2$ $\mathrm{cm}$

e. Perancangan ulang ruang dalam handel = $10.8 \times 4.7 \mathrm{~cm}$

f. Penambahan penyangga yang juga berfungsi sebagai pengalir udara pada punggung.

\section{DAFTAR PUSTAKA}

Annete, S.P. and Jen, A.H., 1994, The working positions of school children, applied ergonomics, 25(1), 63-64.

Barroso, M.P., Arezes, P.M., Costa, L.G., Miguel, A.S., 2005., Anthropometric study of Portuguese worker, Internasional Journal of Industrial Ergonomics 35, 401-410.

Bendix, T., 1984, seated trunk posture at various seat inclinations, seat heights and table height, Human Factor, 26(6), 695-703.

BPS., 2008, BPS dalam angka, Jakarta.

Fagarasanu, $M$ and Kumar, S. "Measurement instrument and Data Collection of Construct and Bias in Ergonomics Research". . 30 (2002). Page 355-369. Industrial Ergonomic.

Hong, Y., Li, J., Wong, A., \& Robinson, P. 2000. Effects of load carriage on heart rate, blood pressure and energy expenditure in children. Ergonomics, 43, 717-27.

Lloyd, R., \& Cooke, C., 2000. The oxygen consumption associated with unloaded walking and load carriage using two different backpack designs. European Journal of Applied 
Physiology, 81, 486-92.

Mahbubah, Nina Aini, 2004, Perancangan tas sekolah model ransel yang ergonomis berdasarkan metode quality function deploymen. Proceedings seminar nasional ergonomic 2, 9 oktober 2004, ISBN 979-97955, I-6, hal 373.

Murphy S., Buckle P., Stubbs, D. 2007. A crosssectional of self-reported back and neck pain among English schoolchildren and associated physical and psychological risk factors. Appl. Ergon. 38, 797 - 804.

Nurmianto, E.,2004. Ergonomi: Konsep Dasar dan Aplikasinya. Edisi Kedua, Guna Widya: Surabaya.

Pietri, F., Leclerc, A., Boitel, L., Chastang, J.F., Morcet, J.-F. And Blondet, M., 2004, “Low-back Pain in Commercial Travelers", Scandinavian Journal of Work, Environment and Health, 18, pp. $52-58$.

Tarwaka, Bakri,SHA (2004). Ergonomi untuk Kesehatan dan Keselamatan Kerja dan Produktivitas. UNIBA Press. Surakarta

Waters, T.R., V. Putz-Anderson, A. Garg, and L.J. Fine. 1993. Revised NIOSH Equation for the Design and Evaluation of Manual Lifting Tasks. Ergonomics 36(7):749-776.

Wignjosoebroto, Sritomo, Teknik Tata Cara dan Pengukuran Kerja, Guna Widya, Jakarta, 1995.

Yanto, Evi situmorang, Herlina, Hotniar Siringoringo, Baba Md Deros. (2008). Mismatch between school furniture dimensions and student's anthropometry (A Cross-Sectional Study in an Elementary School, Tangerang, Indonesia). Proceedings of the $9^{\text {th }}$ Asia Pacific Industrial Engineering \& Management Systems Conference (APIEM 2008). 